\author{
Anne Berit Emstad \\ Norwegian University of Science and Technology (NTNU) \\ Lise Vikan Sandvik \\ Norwegian University of Science and Technology (NTNU)
}

DOI: http://dx.doi.org/10.5617/adno.7934

\title{
School-University Collaboration for Facilitating In-Service Teacher Training as a Part of School-Based Professional Development
}

\begin{abstract}
Achieving equality in school-university partnerships is challenging. In this study, we examined a school-university partnership in Norway and how the partners worked together to facilitate a school-based in-service teacher training programme. For the purposes of this investigation, we used a theoretical framework specifically developed to explore cross-sectoral collaborations in general. Participants included 135 teachers (101 from an upper secondary school and 34 from a lower secondary school) who participated in and graduated from an on-site in-service teacher training programme on "mentoring and research and development" that awarded participants 15 ECTS credits upon completing the programme. We conclude that a relationship of trust is evident in the way the partners collaborated on developing a curriculum for the programme as well as the programme design throughout the implementation of the programme. We argue that the anchoring processes seem to be of great importance in encouraging internal commitment among the different partners involved. Next, we argue the importance of 'boundary-spanning champions' who negotiated and renegotiated the programme design based on close dialogues with the teachers. This was important not only for the internal commitment and trust obtained, but also for the successful design of a schoolbased programme based on both practice and theory.
\end{abstract}

Keywords: school-university collaboration, partnership, school-based in-service training

\section{Tilrettelegging av skolebasert videreutdanning i partnerskapssamarbeid mellom skole og universitet}

\author{
Sammendrag \\ Å oppnå likestilling i partnerskap mellom skole og universitet er utfordrende. I denne \\ studien undersøkte vi et partnerskap mellom skole og universitet i Norge og hvordan \\ samarbeidspartnerne jobbet sammen for å legge til rette for et skolebasert \\ videreutdanningstilbud. Studien bygger på et teoretisk rammeverk som er spesielt \\ utviklet for å utforske tverrsektorielt samarbeid. Studien inkluderte 135 lærere (101 fra \\ en videregående skole og 34 fra en ungdomsskole) som alle deltok og tok eksamen i
}


emnet «Veiledning og FOU», som ga deltakerne 15 studiepoeng. All undervisning var lagt til egen arbeidsplass. Vi konkluderer med at samarbeidet preges av et tillitsforhold som setter sitt preg på arbeidet med utvikling av læreplanen og gjennomføring av videreutdanningen. Vi argumenterer for at forankringsprosessene ser ut til å være av stor betydning for å oppmuntre til intern forpliktelse blant de involverte partnerne. Dernest argumenterer vi for viktigheten av «grensespennende mestere» (boundaryspanning champions) som forhandlet og reforhandlet studieplanen gjennom flere dialoger med lærerne. Dette var viktig ikke bare for den interne forpliktelsen og tilliten som ble oppnådd, men også for den vellykkede utformingen av en skolebasert videreutdanning basert på både praksis og teori.

Nøkkelord: skole-universitetssamarbeid, partnerskap, skolebasert videreutdanning

\section{Introduction}

In the emerging conception of teacher education as continuous education, the practice field and higher education share the responsibility for teacher education; they are partners pursuing the same goal, educating teachers to improve education at all levels (Smith, 2016).

There have been several attempts to respond to the criticism that teacher education institutions allegedly lack interest in the practical field when it comes to developing teacher professionalism from a lifelong perspective. Some countries have chosen to solve conflicts between theory and practice by reducing the efforts of universities and emphasising practice over theory. Several European countries, including Norway, are trying to develop teacher training in the direction of professionalisation (Donaldson, 2011; Menter, Brisard, \& Smith, 2006). This is carried out by strengthening research in education and establishing more committed partnership models between teacher education and practice schools. Different kinds of partnerships have become one of the concepts employed to try to balance the roles of schools and teacher education institutions in the training of teachers from a lifelong perspective (Haugaløkken \& Ramberg, 2007; Lillejord \& Børte, 2016). Since the 1990s, for example, a growing part of teacher education in England has been placed in the schools (Hayes, 1999). Ellis (2010) argued that transferring a greater portion of education to schools does not solve the fundamental question in teacher education and teacher professionalism, which is how to create practice-developing research through collaborations among school teachers, university staff and student teachers. In a literature review based on 278 articles as well as 12 review articles from the period 2009-2011, Postholm (2012) provided an overview of previous research related to teachers' learning and concluded, based on the review, that in-school learning provides the best arena for continuous teacher learning and development, and that both individual and organisational factors impact teachers' learning.

Sandholtz (2002) distinguished between in-service teacher training (ITT) and professional development, as she studied opportunities offered by school- 
university partnerships for teachers in four schools all affiliated with the same university. ITT is defined as a model based on the transmission of information from someone with authority, and school-university partnerships give teachers the opportunity to select activities that best meet their current needs and teaching situation while also providing multiple and varied professional development opportunities directly related to their classroom teaching. Sandholtz (2002) argued that teachers ascribe greater validity to the views of their peers than to the views of external experts, adding that collaboration with peers allows teachers to critically examine their own work in ways that lead to new knowledge. In another article presenting a case study, one which examined a school-university partnership in the United States, the authors concluded that collaborative efforts between schools and universities may enhance teachers' professional development, even though divergent goals and differing views of teaching may affect the work and make it harder to build learning communities (Bartholomew \& Sandholtz, 2009).

ITT as an opportunity to enhance teachers' professional development is criticised for being segmented from teachers' regular work, as the two are often disconnected in both substance and setting (Fullan, 1995; Sandholz, 2002), and Avalos (2011) claimed that there has been a movement away from the traditional ITT model.

In an international review of research on partnerships in teacher education, Lillejord and Børte (2016) reported that the biggest challenge in partnerships seems to be how to achieve equality between the two partners, and the authors argued the need for committed and competent leadership both in the establishment phase and in the operational and renewal phases of a partnership. Lillejord and Børte (2016, p. 12) also drew attention to the tension caused by the historically dominant position of teacher education institutions in education. Furthermore, they pointed out that schools do not experience real contribution to education and highlighted the 'third space', which is a term several researchers use to describe where interaction processes between actors in teacher education take place. The third space is often used to visualise the possibilities that lie in closer cooperation among aspects that currently appear only as loosely connected parts in professional education. The concept of the third space was first developed in depth by Bhabha (1994) as a metaphor for the space in which cultures meet. Third spaces can be seen as more democratic and dialogical spaces than traditional collaborations as well as metaphors for spaces in which new, hybrid and challenging discourses and real-world knowledge and applications are created. The newly established culture of a third space is an environment that should provide the space for the development of new communities of practice involved in shared learning and interactions (Sutherland, Scanlon \& Sperring, 2005) as well as the potential for dialogue, reflection and transformation, all of which are seen as key competencies for teacher professionalism. School-university partnerships have different structures and content, but partnerships usually consist of parties 
that have common goals that cannot be reached by either party independently (Barnett, Hall, Berg, \& Camarena, 1999; Roberts, 2001).

This article discusses a potential solution to developing more sustainable partnerships and professionalisation in teacher education by using an example from a school-university partnership in Norway, which has facilitated ITT as a part of school-based professional development on site for teachers. In this study, we explore how this ITT training programme on mentoring and research and development (hereafter abbreviated R\&D) was facilitated and implemented as part of a school-university partnership: a three-part partnership among the university, three schools and their superiors at the county municipality and municipality levels. The research question guiding the study is: What characterises school-university collaborations viewed from the perspectives of collaborative processes, governance and constraints when planning and implementing an ITT programme on mentoring and $R \& D$ ? To explore this, we used a theoretical framework of Bryson, Crosby and Stone (2006) that was developed to explore cross-sectional collaborations in general. In the current study, we investigate how the partners worked together to facilitate a school-based ITT programme.

Most partnerships, however, incorporate some type of professional development (Callahan \& Martin, 2007). In the current context, a partnership is meant to be an attempt to face the challenges of creating sustainable partnerships in teacher education, and the school-based mentoring and $\mathrm{R} \& \mathrm{D}$ programme can be considered as a new space where university researchers, school leaders and coordinators use dialogue, knowledge and experience to develop the programme together. Research refers to these common spaces as hybrid spaces that connect campus courses and field experiences in university-based preservice teacher education (Zeichner, 2010; Zeichner, Payne \& Brayko, 2015). These spaces involve teachers, student teachers and university staff in working across boundaries of research and teaching practice, thereby developing teacher professionalism. In turn, teacher professionalism requires this research-based competence to develop both individuals and schools within educational systems. Professionalism has been the subject of many studies, but still teacher professionalism remains a contested topic. In this study we draw on Sachs (2016), who concludes that teacher professionalism is about creating discursive spaces whereby a collaborative or research-engaged teaching profession develop and thrive, having a shared vocabulary about practice and how to improve that practice by engaging in systematic inquiry, developing strategies to constantly improve and be innovative in their practice, and sharing that practice (p. 424).

\section{Description of the case}

The point of departure is a school-university partnership involving the department of teacher education in a Norwegian University, one upper secondary school with 
1,100 students, a lower secondary school with 430 students, a primary school with 550 students and the Municipal Education Office. All the schools are among the many where student teachers undertake their teaching practicums.

The overall aim of this partnership was to create a new and improved arena for teacher education, which would empower student teachers and in-service teachers to be proactive and reflective professionals.

To "strengthen the school's ability to develop systematically and improve teachers' skills" and "strengthen teacher education", the first initiative in the partnership was a school-based in-service education in R\&D work, awarding participants 15 ECTS credits at master's level upon completing the programme. 135 teachers participated, and they worked with their colleagues in groups of three to four to plan and conduct an action-learning project that formed the basis for their examination text. 'School-based' means that the education was offered on site, adjusted to the school's needs and context, and that the R\&D projects were conducted in the teachers' classes and, for some, in collaboration with their student teachers.

The university schools were chosen by municipality, county municipality and university stakeholders, following a comprehensive application process. Each selected school appointed a coordinator, who was the contact person between the school and the university. In addition to the coordinators, several resource teachers were appointed, all of whom were experienced mentors and were required to contribute to the on-site ITT programme. This study is based on just two of the schools, as the third one had not yet been appointed when the study started.

At the university, a professor was appointed manager of the mentoring and $\mathrm{R} \& \mathrm{D}$ programme. To facilitate communication and discussions between groups of participants, the schools were asked to appoint resource teachers. The resource teachers had previously completed a supervisor education programme, and they were informed about the study's knowledge base and methodology before it started. Each resource teacher supported the work of 12-15 participants in the more in-depth tasks of the study.

All in all, 135 teachers from the two schools were given the opportunity to participate in the programme. Guided by the resource teachers and the university teachers, they planned and conducted an R\&D project that formed the basis for the text of their examination.

\section{Analytical framework of the study}

Based on a review of existing literature, Bryson et al. (2006) developed a theoretical framework for exploring cross-sector collaborations. This framework formed the basis for our analysis process. 
The decision to collaborate across agencies, entities and sectors arises for many reasons. Based on shared responsibilities, parties may choose to collaborate so that they can deal with public challenges, and network and collaboration constellations may also be formed in response to a longstanding critique of the ability of the public authorities to meet these challenges (Roberts, 2001). Interagency and cross-sector collaborations exist because it is not possible to reach one's goals alone; the goals cannot be attained without cooperating with others. Bryson et al. (2006, p. 44) defined a cross-sector collaboration as "the linking or sharing of information, resources, activities and capabilities by organisations in two or more sectors to achieve jointly an outcome that could not be achieved by organisations in one sector separately', and the authors pointed to the following as key elements that influence collaboration:

- Initial conditions

- Processes

- Structure and governance

- Contingencies and constraints

- Outcomes and accountabilities

The term initial conditions refers to the general surroundings and the challenges that were present prior to the collaboration; it might also refer to mutual understandings that were present when it comes to these challenges. Insight into one's own interests accompanying recognition of reciprocal dependency may be a good premise for successful collaboration (Logsdon, 1991). This may mean, for example, that uncertainty is reduced and organisational stability is increased. The start-up conditions may influence processes, structures and governance when the collaboration is launched and followed up on. A 'collaborative mind-set' is important for leaders involved in collaborations, and such boundary-spanning leaders are called sponsors and champions in the literature (Crosby \& Bryson, 2010; Cikaliuk, 2011). Sponsors and champions are both important for the initial conditions and during the processes of implementation of the collaboration.

Processes, as well as structure and governance, may also lead to mutual challenges that impact commitments and restraints in the collaborative relationship (Bryson et al., 2006). These include establishing the legitimacy of the collaboration when it comes to internal and external stakeholders. A key process in a collaborative effort is to maintain dialogue and the ability to negotiate and renegotiate goals and agreements, even after the collaboration has been initiated (Bryson et al., 2006, p. 46). When the parties have agreed to cooperate, focus is also required on structures, roles, division of responsibilities and decision-making authority. Agreements in these areas must be developed and discussed on an ongoing basis by key stakeholders in the collaboration. These dialogues are important for how the collaboration functions and how equality in power relationships is maintained (Bryson et al., 2006). 
One important element in all of this is the need to build leadership. Logsdon (1991) asserted that both self-interest and recognised mutual dependency are necessary requirements for collaboration. Gray (1989) pointed out that collaborative constellations may also arise from the engagement of individuals that have specific individuals as facilitators or conveners. Conveners are people with legitimacy and credibility who are involved in the problem and find stakeholders able to work together to solve the problem. The forms of collaboration that arise, balance of power among the parties and differences in institutional logic may bind and constrain possible outcomes of the collaboration. The parties should formalise agreements, mission statements, mandates and resource use and set up formal leadership and formal decision-making structures. Doing so impacts the level of flexibility established to deal with local conditions and changes (Crosby \& Bryson, 2005). To maintain a collaborative project, both sponsors and champions may be needed (i.e., people with control of resources that can be allocated to contribute to the collaboration, and people working to keep the collaboration going) who focus on the problems at hand and on ensuring that actions are taken so that the desired outcome of the collaboration is achieved (Bryson et al., 2006).

In order to discuss our findings, we also draw on the theory of Argyris (2000), who distinguished between two types of commitment, internal and external. He considers internal and external commitment as equally valuable in creating persistence, endeavours and vigilance when working towards improvement and change. External commitment is triggered by management policies and practices that enable employees to accomplish their tasks, whereas internal commitment derives from energies internal to human beings that are activated because getting a job done is intrinsically rewarding. Internal commitment is related to individuals having a significant influence on defining goals and ways to achieve them, and it is possible to build internal commitment by involving them in defining values and goals, while external commitment exists when someone else defines objectives, goals and steps to be taken to reach them (Argyris 2000, p. 41).

Argyris (2000) also indicated that it is important to make the distinction between internal and external commitments explicit but, nevertheless, to find ways to develop internal commitment. Research has shown that teachers' sense of professional and personal identity is a key variable in their professional motivation and commitment (Day, 2002; Thoonen, Sleegers, Oort, Peetsma \& Geijsel, 2011).

\section{Method}

A qualitative research approach (Creswell, 2002) was utilised in this study to investigate the phenomenon of collaboration on a school-based ITT programme in a school-university partnership. A single case study (Stake, 2005) was used to investigate the planning, implementation and outcomes of the collaboration. Stake 
(2005) claimed that case studies can assist the reader in the construction of knowledge. A case study approach is appropriate when the phenomenon is a temporary one that can be studied in its natural context and when the boundaries between the phenomenon and the context are unclear (Stake, 2005; Yin, 2003). Through reflective work, we as researchers describe and interpret multiple sources of data, dig into opinions and work in order to relate our data to context and experience (Stake, 2005). By triangulating our varied sources of data, we can obtain multiple perspectives and points of view in order to get a better understanding of the phenomena. Accurate descriptions and disciplined interpretations that preserve respect for different conceptions of the phenomenon are described by Stake (2005) as an "extension of experience" that can be of value in refining theories, understanding complexity and seeing limitations in generalisations. The present case was chosen because it is an example of how 135 teachers (101 from an upper secondary school and 34 from a lower secondary school) participated in and graduated from an ITT programme (awarding 15 ECTS credits) on mentoring and R\&D given on site, in their own work context. This may reveal relevant information about how this apparent success story was achieved. The ITT programme provided an opportunity for teachers to improve their skills as mentors of student teachers and colleagues.

The data was obtained from three semi-structured interviews, with two school coordinators (in collaboration with the programme manager from the university) and one interview with the programme manager. The questions were related to:

- The background and purpose of further education

- The anchoring of the processes

- Involvement in and descriptions of planning, implementation and followup processes

- Role-related experiences of the overall process

- Results experienced

Additionally, eight semi-structured focus group interviews with a total of 35 teachers participating in the programme were conducted, both before and after they participated in the programme. The teachers were asked about the content of the mentoring conversations, to what extent their practice was anchored in theory and practice, and their expectations of and what results they had experienced from the mentoring and $\mathrm{R} \& \mathrm{D}$ programme with regard to collaboration with colleagues in the programme and on-site ITT.

In addition, we read and analysed documents that provided us with relevant information. These consisted of the curriculum for the ITT programme and an unpublished report written by the programme manager and a colleague, based on examination texts.

The interviews were transcribed and then analysed in order to describe, understand and explain the characteristics of the school-university collaboration. The analysis for each interview was conducted on the basis of the Bryson et al. 
(2006) theoretical framework, and their key elements were used as categories for organising the data from the interviews. Then we did the same with the documents in order to triangulate the data. Table 1 provides an example of the categories and how we systematically ordered the data into those categories, as well as an example of how we ordered the data. We did the same categorisation with all the data (interviews with teachers and coordinators and the document analysis).

Table 1. Example categorisation

\begin{tabular}{|c|c|c|c|c|c|}
\hline \multicolumn{6}{|c|}{ Extract from the analysis process } \\
\hline & $\begin{array}{l}\text { Initial } \\
\text { Conditions }\end{array}$ & Processes & $\begin{array}{l}\text { Structure and } \\
\text { Governance }\end{array}$ & $\begin{array}{l}\text { Contingencies } \\
\text { and Constraints }\end{array}$ & $\begin{array}{l}\text { Outcomes and } \\
\text { Accountabilities }\end{array}$ \\
\hline $\begin{array}{l}\text { Programme } \\
\text { manager }\end{array}$ & $\begin{array}{l}\text { Supervisor } \\
\text { training is a } \\
\text { tool for } \\
\text { improving } \\
\text { the school's } \\
\text { R\&D } \\
\text { competence. } \\
\text { At the same } \\
\text { time, the } \\
\text { school is } \\
\text { keen on } \\
\text { professional } \\
\text { school } \\
\text { development. }\end{array}$ & $\begin{array}{l}\text { Two } \\
\text { processes: } \\
\text { 1. Anchoring } \\
\text { with the } \\
\text { programme } \\
\text { manager and } \\
\text { advisory } \\
\text { board, where } \\
\text { there are also } \\
\text { two } \\
\text { coordinators. } \\
\text { 2. Anchoring } \\
\text { of programme } \\
\text { design: } \\
\text { collaboration } \\
\text { with } \\
\text { colleagues at } \\
\text { the university, } \\
\text { coordinators, } \\
\text { and the school } \\
\text { management. }\end{array}$ & $\begin{array}{l}\text { Professional } \\
\text { anchoring } \\
\text { towards the } \\
\text { teachers. A } \\
\text { colleague of } \\
\text { mine, who also } \\
\text { participated in } \\
\text { the seminar } \\
\text { itself, and we } \\
\text { used resource } \\
\text { teachers as well. } \\
\text { They were } \\
\text { involved in the } \\
\text { planning phase } \\
\text { of the seminar. } \\
\text { We had a } \\
\text { meeting with } \\
\text { them before we } \\
\text { started and } \\
\text { explained their } \\
\text { tasks and } \\
\text { organisation. }\end{array}$ & $\begin{array}{l}\text { The study plan: } \\
\text { new theories } \\
\text { were presented } \\
\text { to coordinators } \\
\text { and resource } \\
\text { teachers in the } \\
\text { development of } \\
\text { the study plans. } \\
\text { It was a tedious } \\
\text { process with } \\
\text { many questions } \\
\text { and frustration } \\
\text { among those } \\
\text { from the } \\
\text { schools. We } \\
\text { had } \\
\text { discussions; } \\
\text { they came up } \\
\text { with } \\
\text { suggestions, } \\
\text { and we made } \\
\text { adjustments. }\end{array}$ & $\begin{array}{l}\text { Evaluations } \\
\text { indicate that } 70 \\
\text { percent of the } \\
\text { teachers' } \\
\text { development as } \\
\text { supervisors is } \\
\text { supported by } \\
\text { theory and } \\
\text { models in the } \\
\text { curriculum. } \\
\text { This has helped } \\
\text { to develop their } \\
\text { constructive } \\
\text { and critical } \\
\text { understanding; } \\
\text { if so, this could } \\
\text { be seen as } \\
\text { important. }\end{array}$ \\
\hline
\end{tabular}

The framework by Bryson et al. (2006) form the structure of the presentation and the discussion of the data. Although great caution must be exercised when making generalisations in relation to such a small sample of programmes and principals, we follow Stake's (2005) call for the use of naturalistic generalisations, which means that the readers can relate to the research findings if they intuitively fall naturally in line with their own everyday experiences.

\section{Empirical Findings and Discussion}

\section{Initial Conditions}

Even when environmental conditions favour the formation of a cross-sector collaboration, it is unlikely that it will start without the presence of more specific drivers or initial conditions (Bryson et al., 2006). In this particular collaboration, 
there was a formalised agreement on the table between the university and the municipality, and the schools had to apply and compete with other schools to be a part of that collaboration. The coordinators in both schools said it was part of the overall agreement that the school was required to apply to become a university school, and there was a positive attitude towards the opportunities provided in the agreement for both the teachers and the school. The content of the partnership agreement committed the schools to educate mentors for teacher education.

In addition to these initial conditions, it is possible that the self-interest of both parties concerning the improvement of both school and teacher education, worked as an important precondition that contributed to perceived interdependence by the parties involved (Logsdon, 1991). When articulating the mission of the partnership and the in-service training, the two coordinators and the programme manager - highlighting the mutuality of the collaboration - said it was to develop both the school and teacher professionalism as well as to qualify mentors for the development of the teacher education programme. The programme manager exemplified this through the following quote:

It's about strengthening the school's ability to develop systematically and improve teachers' skills. In addition, it would strengthen teacher education through greater integration of discipline subjects, pedagogy, subject content knowledge, vocational studies [and] school practice and to do R\&D work at school. So that's the big picture. So that's the reason for it.

The coordinators also emphasised that the opportunity to obtain credit points while being together in their own work context with colleagues, contributed to the high numbers of teachers committed to participating.--especially in the lower secondary school.

Cross-sector collaborations are more likely to succeed when one or more linking mechanisms - such as powerful sponsors, general agreement on the problem, or existing networks - are in place at the time of their initial formation (Bryson et al., 2006, p. 46). We have already mentioned the framework agreement that formed the basis of the participation in the ITT programme, but in addition to this, the collaboration also had the advantage of existing networks. The university had been sending its student teachers for practical training to both schools for many years before the formal agreement on the school-university collaboration was signed, and both coordinators knew the programme manager from earlier collaborations. This may have enhanced the trustworthiness and the legitimacy of the programme manager (Bryson, Crosby \& Stone, 2015).

The analysis of the initial conditions indicated that there was some external commitment (Argyris, 2000) related to the partnership agreement, including the obligation to participate in the ITT programme. An external commitment may not induce enough motivation for participation in the programme; it is necessary to examine other categories - processes, structure and governance - to understand 
and look critically at how planning the content and implementing the ITT was carried out.

\section{Processes, Structure and Governance}

Bryson et al. (2006, p. 44) proposed that the form and content of the initial agreements of a collaboration, as well as the processes used to formulate them, affect the outcomes of its implementation. The authors also emphasised the importance of building trust and asserted that trusting relationships are both the lubricant and the glue of collaborations.

Vangen, Hayes and Cornforth (2015, p. 1244) offered a useful definition for governance of a collaboration, saying that it may "entail the design and use of a structure and processes that enable actors to direct, coordinate and allocate resources for the collaboration as a whole and account for its activities". In the present collaboration, the content and structure of the in-service programme were forged in a dialogue among the coordinators, resource persons and the programme manager while developing, implementing and following up on a study programme /further education for mentors. Our analysis shows that there were essentially two processes taking place while forging the plan: one was the development of the curriculum and the design of the programme itself; the other was the implementation of the in-service programme.

The first process involved the coordinators, resource teachers, school leaders and programme manager at the university. The study plan was forged through three meetings that took place even before the first draft of content was ready; one more meeting took place after the draft was finished. The programme manager said that the aim of this initial process was primarily to create a professional foundation with regard to the teachers by building on the knowledge of the context held by the school and the knowledge of teacher and mentor education - based on research - held by the programme manager. Another aim was to build on structures that enabled the programme to be a part of the workday for the teachers; this process included collaborations with the unions and local authorities (school owners).

The second process was related to the implementation of and follow-up on the programme, which were also undertaken in a context of close relations between the schools and the university. The two participating schools ended up with different agreements with regard to the use of time. The upper secondary school offered teachers 10 hours' compensation for their participation in the further education programme, while in the lower secondary school, the resource person received time off from lessons. Both agreements were drafted in collaboration with the teacher unions. In both schools the school time ordinarily used for collaboration among teachers was used for both lectures and tasks related to further education. The coordinators said they spent time motivating the teachers to put in extra efforts, but stated that most of the teachers acted in a self-regulated way during their studies. 
Once the ITT started, the close relations between the schools and the university continued. To facilitate professional anchoring, every session was presented and discussed in a meeting beforehand and evaluated afterwards. There seemed to have been a relationship of trust among the collaborative parties. The data indicates that the processes were inclusive, and there was no trace of statements that show power imbalance. These two processes may be interpreted as the continuous trust-building activities during which legitimacy was built in the course of ongoing processes (Huxham \& Vangen, 2005; Suchman, 1995).

These kinds of inclusive structures may have facilitated the governance of the collaboration as the processes mentioned were focused on the involvement to instil a sense of relevance and commitment among the participants (Bryson et al., 2015). The programme manager stated, "We used teachers who had previously participated in a mentor programme at [the] campus as resource teachers and involved them in the planning phase of the programme design.” The programme manager explained the importance of including the resource teachers in the planning, along with the importance of both organisational and professional anchoring:

We actually started first with the professional anchoring to thereby connect the substance to the 12 resource teachers. And the next thing was to get an organisational anchorage using their knowledge about the school. The processes flowed well due to their knowledge of the context.

The intention was to build a programme structure that could be implemented during the workday and guided by the structure of the school contexts. This is evident in the form and content of each session, where the articulated aim was to maintain relevance for the teachers. The programme manager explained how he used many varied working methods in which he would go from their own practice through different communicative spaces, in which they presented and discussed their understanding of theory related to their own practice:

That's all the theory is about, so it's a kind of practice theory. And that's where we worked on the production of posters and other shapes as they showed up, and we worked consistently with IGP [Individual, Group, Plenum], first led individually by resource teachers. In a small plenary, it was the small group of 10-12 people. The big plenary was used mostly at the lower secondary school, because there were up to 40 people, and sometimes, a large plenary in the upper secondary school - where there were 101 [people] present in a large auditorium, which was a bit difficult. So you could say that the resource teachers were actively used, both ahead of the seminars and afterwards.

Using terms from Bryson et al. (2006, p. 47), we have identified the roles of the coordinators and the programme manager as boundary-spanning champions, individuals who focus intently on keeping the collaboration going and use process skills to help the collaboration accomplish its goals. In this collaboration the coordinators and the programme manager describe how, through several meetings, they adjusted the curriculum and the programme design. These 
continuous interactions may have contributed to building legitimacy and trust between the partners as they shared information and knowledge while forging the content of the in-service programme through building on the distinctive competencies of the collaborators, including contextual knowledge about the school and the teachers who would be involved in the ITT programme (Bryson, Ackermann \& Eden, 2007).

\title{
Contingencies and Constraints
}

One evident contingency that inhibited trust seems to be the competence of the programme manager. He demonstrated this competence when he described two concept layers of building the programme design. First, it was built on research on mentoring; second, it was built on research on teacher education and ITT. He said:

\begin{abstract}
That it should be, first of all, on the research front. Next, it should be school-based. This means that it should be linked with the subjects in the schools, the different programme directions that are there, so that it becomes contextual. We had a clear idea that practice education is practice related to teachers' tasks - that is, guiding future teachers whereas profession is connected to subjects, school, the level of the student group (teachers participating in the programme), etc. That was my main idea when we started this.
\end{abstract}

These layers were combined while developing the programme design and then developed even further in follow-up dialogues between the schools and the university. The contribution of the two layers, together with the dialogical process, may have contributed to the pragmatic legitimacy because it seems that through these two processes, an internal commitment was established among the participants (Argyris, 2000; Suchman, 1995).

The gap between internal commitment and external commitment may become a constraint when implementing an ITT programme for all the teachers in a school, but our findings indicate that the gap was balanced by means of contextualising the ITT programme and adjusting it to the schools' structures. Some of the tension was related to the content and the structure of the programme. The resource teachers feared it would be too much work, and they struggled to understand their role. The coordinators had to take time to explain and calm the situation. Their tension was also related to the theoretical framework used in the programme, as the resource teachers found it hard to grasp. One of the coordinators said:

It was a relatively heavy process because, I mean, remembering that after the first two hours we had with them [the resource teachers], there were many questions. And people were a little bit frustrated because there was so much that was new, and I made a suggestion that they also looked at and adjusted to. And that the programme design was finalised before Christmas. But then the teachers started to loosen up when they began to get hold of the main theory about the practice architecture and the understanding of it. 
Once the resource teachers understood the theoretical framework, they were able to proceed with planning the content of the study programme. This was an example of the openness and flexibility that seemed to be present during the collaboration, an openness that was maintained by means of dialogues and the ability to negotiate and renegotiate goals and agreements. These ongoing trustbuilding activities may have helped bridge the asymmetry between universities and schools that had been of concern in several school-university collaborations studied (Lillejord \& Børte, 2016) and contribute positively to the governance of the collaboration.

In the interviews with the teachers, we also spotted some tension described by the teachers who took the further education programme. These teachers struggled with the workload related to the studies: some felt that the theory was relevant, some others felt it was banal, and another group thought it was too hard to grasp. One of the teachers said:

... because it's a very special situation when you are a teacher, giving 100 percent and then are given 25 percent more [for] study on top of that without getting relief. And then you have 500 pages of [the] syllabus to read. So, basically, you say you do not have a chance to prioritise it, but once you sit down and read, you notice that there are terrible words - that is, terribly many words. It takes time to sink [them] in, and you do not have the time. They have not adapted the syllabus to us.

Finally, the data show that there were also constraints due to the use of time, even though the opportunity to work in groups made it a bit easier:

... have been a real boost. I was negative because I have only taught for a short time as a teacher. So all this came on top of everything, and we've had quite some time off from teaching and meetings. We are all teachers; we have a lot to do. But now that we're done, I'm proud. It is such a collective pride for the school and for me too. [It] seems I'm very happy and have to say I like working very well in groups ... like, very well, working with other colleagues. Fortunately, there was no individual work in the study.

With regard to identifying teachers' perceptions of the in-service programme in terms of internal commitment, Ryan and Deci's (2003) work on relations and relatedness includes terms such as enjoyment, sense of purpose and well-being when describing a person's engagement in activities, which can help in understanding mentor commitment. If a person identifies with the activities to be performed, the quality of engagement is higher. On the one hand, it may seem that some teachers felt that the programme they undertook was not related to their daily work and that the work overload would inhibit an internal commitment to the programme. On the other hand, other teachers underlined how important collaboration with colleagues was during the programme and the fact that the programme was school-based gave them a sense of pride and great satisfaction.

Fullan (2007) built on the theories of Argyris (2000) when focusing on the importance of fostering internal commitment while working for change and development in schools, arguing that external commitment is still commitment, 
as it is the motivation to put one's effort into the task of change. When implementing, for instance, a new programme in a school, a lack of inner motivation may lead to employees distancing themselves from that programme. Activating the ideas and intrinsic motivation of the members of the school is important, as there is a link between knowledge-building and internal commitment on the way to making good things happen in schools (Fullan 2007).

\section{Outcomes and Accountabilities}

Outcomes have been understood by some researchers in terms of first-, secondor third-order effects (Innes \& Booher, 1999). In our study, there were immediate results of the collaboration that corresponded to first-order effects: the development and the implementation of the curriculum and the credit points acquired by the teachers as the teachers passed their exams. The second-order effects may be seen as the changes in practice reported by the participating teachers. The thirdorder effects may be viewed as entailing the development of a model for "on-site further education" as a part of school-based professional development.

First of all, as outlined above, an ITT programme was developed to fit the two schools by means of interaction between members of the university and schools, and 135 teachers received credits for attending and passing exams in the programme.

Second, the programme manager pointed to an evaluation report showing that 70 percent of the teachers said that they felt that the theoretical models from the curriculum had contributed to developing their constructive and critical skills. The school coordinators said that they felt a collective lift from the creation of a common language among the teachers. Most of the teachers themselves spoke of a change in practice and in more theory-based teaching practices, like this teacher who states:

You develop a critical awareness, a reflection around what the student does, as you say how you do it in the classroom in addition to the development of a meta-language, a professional language, and being more aware of how to use it in guidance with the student. Our own experience is important, and being able to use theory to argue, I think, is something that further education has contributed. It's not just an idea that it has worked - but being able to use theory to substantiate and justify the choices that are made, the didactic and the professional.

Even though some of the teachers thought it was hard work, most of them found the programme relevant, and it led to changes in both thinking and practice. What seems to be a source of motivation was the fact that they did the programme together. The programme design invited teachers to work collectively: students in groups of three or four, who taught the same subject, had to deliver an essay of up to 2,000 words. This was the subject's examination text, in which students were required to explore and analyse guidance practices and put them into a theoretical context. In addition to this, the teachers experienced a change in their daily discussions; they acquired a common language about mentoring and $\mathrm{R} \& \mathrm{D}$, and 
the coordinators reported that theory was used in daily discussions among the teachers. One of the coordinators said:

I experienced it as a big collective boost at the departmental level, for example, and that you share experiences to a greater extent. You had shared experiences earlier, but you have become more aware and more critical of the choices you make. One is more closely linked to the theory we were involved with - experience that the school really has ambitions, clear ambitions, that we want to improve our own practice to promote students' learning.

Besides the contribution to learning and competence building for teachers, the coordinators and the programme manager also pointed out the importance of the contribution to a model for ITT within work hours, and one of the coordinators stated:

We will try to create a system that can actually be taken over by someone else if the prerequisites are there, but what does it require? Yes, it requires such and such an amount of time and money and people.

This may be interpreted as a form of accountability for the input of resources the municipalities have invested in the collaboration - especially if the schools feel accountable for the money invested in this collaboration, which means less money invested in the other schools in the municipality/county. Bryson et al. (2015) framed this kind of accountability as focused on public value creation, as it reflects concern for substantive outcomes due to the costs of the collaboration. However, there do not seem to be any accountability issues between the university and the schools themselves.

\section{Concluding Remarks}

From the above theoretical framework, empirical analysis and discussion, we conclude that the data indicates a relationship of trust in the way the coordinators and the programme manager collaborated, not only during the process of developing a curriculum and designing a programme, but also throughout the implementation of the programme. Both the school and the university participants represent their organisations, but, first and foremost, they represent the knowledge they bring to the table - on the context, people, research, and so on - that forms the basis of the collaboration that balances the power relations between them. The collaboration structure seems to be influenced by the collaboration's strategic purpose and not by the roles of the collaborators.

We have identified several dimensions that could inhibit or promote an equal partnership in a school-university collaboration. First, the anchoring processes entailed in the establishment of the university schools seem to be of great importance in creating internal commitment among the different partners 
involved. There was a great deal of self-interest on both sides, the schools and the university, because both parties had stated the benefits of joining the collaboration. On-site ITT was an opportunity to enhance teachers' professional development, and the way this school-university partnership met this challenge was by directly answering the criticism of ITT as being disconnected from teachers' work, both in substance and setting (Fullan, 1995; Sandholtz, 2002). Despite teacher reports of tension regarding the use of time and professional challenges, our findings indicate that teachers experienced both professional development and a pride in having accomplished the programme, as well as feelings of personal growth.

Second, the way the coordinators and the programme manager collaborated to develop the programme design of the ITT programme on mentoring and R\&D seems to have enhanced inclusive structures among teachers taking the programme and the university providing the programme. We have called these individuals boundary-spanning champions to illustrate how they constantly negotiated and renegotiated the programme design based on close dialogues with the teachers. The collaboration between the coordinators and the programme manager was based on trust, and the way they managed to make it school-based - by listening to the schools' needs - helped to develop internal commitment among the teachers. In these sustainable partnerships based on equality, there is a need to establish a joint consensus regarding roles, rights and responsibilities to allow for solid relations between school-based teachers and university-based teacher educators (Smith, 2016). It seems that using boundary-spanning champions, as has been done in this partnership, to establish third spaces (Zeichner, 2010), spaces where both school and university can meet and discuss, negotiate and renegotiate, can promote equality in partnerships of this type.

Third, the school-university relationships and mentor education based on the construct 'inquiry as stance' (Cochran-Smith \& Lytle, 2009) can provide new opportunities for student teachers to become socialised into teaching by participating in an investigative community focused on inquiry-based practices. Such partnerships have mentoring and R\&D as the key elements in the collaboration, and the first step has been to enhance teachers' mentoring and R\&D skills in an in-service programme. Combining practical skills with the ability to understand and use research and other evidence to develop teaching practices defines reflective practice and serves as a foundation for teacher education (Cochran-Smith \& Lytle, 2009). Being a reflective practitioner involves engaging in critical thinking and justifying pedagogical decisions. As Hargreaves (2007) noted, using research evidence is one way teachers can integrate knowing 'what and how' with knowing 'why'. School-university collaborations based on 'inquiry as stance' for all parties involved could be an effective approach to integrating teacher educators at all levels in the school system to create a better school and better teacher education.

This single case study provided relevant information on what characterises a partnership in terms of collaborative processes in one special in-service teacher 
education programme. It provided the knowledge of initial conditions, processes, structure and governance, contingencies and constraints, outcomes and accountabilities that characterised the work of this programme. The findings are not generalisable, but they can make an important contribution to the knowledge of how to develop sustainable partnerships in teacher education.

\section{About the authors}

Anne Berit Emstad is Innovation Manager in the Department of Teacher Education, Norwegian University of Science and Technology. Her responsibility is to realise more of the innovation potential in research and research collaboration. She is also Associate Professor in pedagogy and educational leadership. She has experience as teacher in primary and secondary schools, and served as deputy head of Department of Teacher Education 2013-2016. Her research interests are school leadership and school leaders' professionalism, professional development, school development, teacher education and newly educated teachers.

Institutional affiliation: Norwegian University of Science and Technology (NTNU), Department of Teacher Education, 7491 Trondheim, Norway.

E-mail: anne.emstad@ntnu.no

Lise Vikan Sandvik is a Professor in professional development in the Department of Teacher Education, Norwegian University of Science and Technology. She has experience as teacher in secondary school, and served as deputy head of Department of Teacher Education 2013-2016. Her professional field of interest has mainly revolved around issues of educational assessment, professional development, partnerships in teacher education, and mentoring of preservice teachers. She currently leads a research project on a school-based professional development project that aims to develop assessment literacy among leaders and teachers in 21 upper secondary schools in Norway. Institutional affiliation: Norwegian University of Science and Technology (NTNU), Department of Teacher Education, 7491 Trondheim, Norway. E-mail: lise.sandvik@ntnu.no

\section{References}

Argyris, C. (2000). Flawed advice and the management trap: How managers can know when they're getting good advice and when they're not. Oxford: Oxford University Press.

Avalos, B. (2011). Teacher professional development in teaching and teacher education over ten years. Teaching and teacher education, 27(1), 10-20.

Barnett, B. G., Hall, G. E., Berg, J. H. \& Camarena, M. M. (1999). A typology of partnerships for promoting innovation. Journal of school leadership, 9(6), 484-510. 
Bartholomew, S. S. \& Sandholtz, J. H. (2009). Competing views of teaching in a schooluniversity partnership. Teaching and teacher education, 25(1), 155-165.

Bhabha, H. K. (1994). The location of culture. London: Routledge.

Bryson, J. M., Ackermann, F. \& Eden, C. (2007). Putting the resource-based view of strategy and distinctive competencies to work in public organizations. Public administration review, 67(4), 702-717.

Bryson, J. M., Crosby, B. C. \& Stone, M. M. (2006). The design and implementation of crosssector collaborations: propositions from the literature. Public administration review, 66(1), 44-55.

Bryson, J. M., Crosby, B. C. \& Stone, M. M. (2015). Designing and implementing crosssector collaborations: needed and challenging. Public administration review, 75(5), 647663.

Callahan, J. L. \& Martin, D. (2007). The spectrum of school-university partnerships: a typology of organizational learning systems. Teaching and teacher education, 23(2), 136145.

Cikaliuk, M. (2011). Cross-sector alliances for large-scale health leadership development in Canada: Lessons for leaders. Leadership in Health Services, 24(4), 281.

Cochran-Smith, M. \& Lytle, S. L. (2009). Inquiry as stance: Practitioner research for the next generation. New York: Teachers College Press.

Creswell, J. W. (2002). Educational research: planning, conducting, and evaluating quantitative. Upper Saddle River, NJ: Prentice Hall.

Crosby, B .C. \& Bryson, J. M. (2005). Leadership for the common good: tackling public problems in a shared-power world. (2nd ed). San Francisco: Jossey-Bass.

Crosby, B. C. \& Bryson, J. M. (2010). Integrative leadership and the creation and maintenance of cross-sector collaborations. The Leadership Quarterly, 21(2), 211-230.

Day, C. (2002). School reform and transitions in teacher professionalism and identity. International journal of educational research, 37, 677-692.

Donaldson, G. (2011). Teaching Scotland's future: Report of a review of teacher education in Scotland. Edinburgh: The Scottish Government. Available from: http://www.gov.scot/resource/doc/337626/0110852.pdf

Ellis, V. (2010). Impoverishing experience: The problem of teacher education in England. Journal of education for teaching, 36(1), 105-120.

Fullan, M. G. (1995). The limits and potential of professional development. In T. Guskey \& M. Huberman (Eds.), Professional development in education: New paradigms and practices (pp. 253-267). New York: Teachers College Press.

Fullan, M. (2007). Leading in a culture of change. San Francisco: John Wiley \& Sons.

Gray, B. (1989). Collaborating: Finding common ground for multiparty problems. San Francisco: Jossey-Bass.

Hargreaves, A. (2007). Teaching as a research-based profession. In P. M. Hammersley (Ed.), Educational research and evidence-based practice (pp. 3-17). London: Sage Publications.

Haugaløkken, O. K. \& Ramberg, P. (2007). Autonomy or control: discussion of a central dilemma in developing a realistic teacher education in Norway. Journal of Education for Teaching, 33(1), 55-69. doi: https://doi.org/10.1080/02607470601098310

Hayes, D. (1999). Opportunities and obstacles in the competency-based training and assessment of primary teachers in England. Harvard educational review, 69(1), 1-29.

Huxham, A. \& Vangen, S. (2005). Managing to collaborate: The theory and practice of collaborative advantage. New York: Routledge. 
Innes, J. E. \& Booher, D. E. (1999). Consensus building and complex adaptive systems: a framework for evaluating collaborative planning. Journal of the American planning association, 65(4), 412-423.

Lillejord, S. \& Børte, K. (2016). Partnership in teacher education - a research mapping. European Journal of Teacher Education, 39(5), 550-563. doi: https://doi.org/10.1080/02619768.2016.1252911

Logsdon, J. M. (1991). Interests and interdependence in the formation of social problemsolving collaborations. Journal of applied behavioral science, 27(1), 23-37.

Menter, I., Brisard, E. \& Smith, I. (2006). Making teachers in Britain: Professional knowledge for initial teacher education in England and Scotland. Educational Philosophy and Theory, 38(3), 269-286. doi: https://doi.org/10.1111/j.1469-5812.2006.00194.x

Postholm, M. B. (2012). Teachers’ professional development: A theoretical review. Educational Research, 54(4), 405-429.

Roberts, N. C. (2001). Coping with wicked problems: The case of Afghanistan. In L. Jones, J. Guthrie \& P. Steane (Eds.), Learning from international public management reform, Vol. 11, Part B (pp. 353-375). New York: JAI Press.

Ryan, R. M. \& Deci, E. L. (2003). On assimilating identities to the self: A self-determination theory perspective on internalization and integrity within cultures. In M. R. Leary \& J. P. Tangney (Eds.), Handbook on self \& identity (pp. 253-274). New York: The Guilford Press.

Sachs, J. (2016). Teacher professionalism: Why are we still talking about it? Teachers and Teaching, 22(4), 413-425.

Sandholtz, J. H. (2002). Inservice training or professional development: Contrasting opportunities in a school/university partnership. Teaching and Teacher Education, 18(7), 815-830.

Smith, K. (2016). Partnerships in teacher education - Going beyond the rhetoric, with reference to the Norwegian context. CEPS Journal, 6(3), 17-36. Retrieved from http://files.eric.ed.gov/fulltext/EJ1128734.pdf

Stake, R. E. (2005). Qualitative case studies. In N. K. Denzin \& Y. S. Lincoln (Eds.), The Sage handbook of qualitative research, Third edition (pp. 443-446). Thousand Oaks, CA: Sage Publications.

Suchman, M. C. (1995). Managing legitimacy: Strategic and institutional approaches. Academy of Management Review, 20(3), 571-610.

Sutherland, L. M, Scanlon, L. A. \& Sperring, A. (2005). New Directions in Preparing Professionals: Examining Issues in Engaging Students in Communities of Practice through a School-University Partnership. Teaching and Teacher Education, 21(1), 79-92. doi: https://doi.org/10.1016/j.tate.2004.11.007.

Thoonen, E. E. J., Sleegers, P. J. C., Oort, F. J., Peetsma, T. T. D. \& Geijsel, F. P. (2011). How to improve teaching practices: The role of teacher motivation, organizational factors, and leadership practices. Educational Administration Quarterly, 47(3), 496-536. doi: https://doi.org/10.1177/0013161X11400185

Vangen, S., Hayes, J. P. \& Cornforth, C. (2015). Governing cross-sector, inter-organizational collaborations. Public Management Review, 17(9), 1237-1260.

Yin, R. K. (Ed.) (2003). Case study research: design and methods. Thousand Oaks, CA: Sage.

Zeichner, K. (2010). Rethinking the connections between campus courses and field experiences in college- and university-based teacher education. Journal of Teacher Education, 61(1-2), 89-99. doi: https://doi.org/10.1177/0022487109347671

Zeichner, K., Payne, K. A. \& Brayko, K. (2015). Democratizing Teacher Education. Journal of Teacher Education, 66(2), 122-135. doi: https://doi.org/10.1177/0022487114560908 